\title{
REVIEW
}

\section{Occupational risk factors for shoulder pain: a systematic review}

\author{
Daniëlle A W M van der Windt, Elaine Thomas, Daniel P Pope, Andrea F de Winter, \\ Gary J Macfarlane, Lex M Bouter, Alan J Silman
}

\begin{abstract}
Objectives-To systematically evaluate the available evidence on occupational risk factors of shoulder pain.

Methods-Relevant reports were identified by a systematic search of Medline, Embase, Psychlit, Cinahl, and Current Contents. The quality of the methods of all selected publications was assessed by two independent reviewers using a standardised checklist. Details were extracted on the study population, exposures (physical load and psychosocial work environment), and results for the association between exposure variables and shoulder pain.

Results-29 Studies were included in the review; three case-control studies and 26 cross sectional designs. The median method score was $60 \%$ of the maximum attainable score. Potential risk factors related to physical load and included heavy work load, awkward postures, repetitive movements, vibration, and duration of employment. Consistent findings were found for repetitive movements, vibration, and duration of employment (odds ratio (OR) 1.4-46 in studies with method scores $\geqslant 60 \%$ ). Nearly all studies that assessed psychosocial risk factors reported at least one positive association with shoulder pain, but the results were not consistent across studies for either high psychological demands, poor control at work, poor social support, or job dissatisfaction. Studies with a method score $\geqslant 60 \%$ reported ORs between 1.3 and 4.0. Substantial heterogeneity across studies for methods used for exposure assessment and data analysis impeded statistical pooling of results.
\end{abstract}

Conclusions-It seems likely that shoulder pain is the result of many factors, including physical load and the psychosocial work environment. The available evidence was not consistent across studies, however, and the associations were generally not strong. Future longitudinal research should evaluate the relative importance of each individual risk factor and the role of potential confounding variables-such as exposure during leisure time-to set priorities for the prevention of shoulder pain in occupational settings.

(Occup Environ Med 2000;57:433-442)

Keywords: systematic review; shoulder pain; risk factors

Shoulder pain is a common problem. The prevalence of shoulder pain in the general population may be as high as $6 \%-11 \%$ under the age of 50 years, increasing to $16 \%-25 \%$ in elderly people. ${ }^{12}$ Inability to work, loss of productivity, and inability to carry out household activities can be a considerable burden to the patient as well as to society. Swedish insurance data show that in 1994 about $18 \%$ of total paid sick leave for musculoskeletal disorders was spent on neck-shoulder problems, which meant that the costs of paid sick leave for neckshoulder pain were almost equal to those of low back pain. ${ }^{3}$

The number of epidemiological studies reporting on potential risk factors for shoulder pain has greatly increased in the past decade. Work related factors are assumed to play an important part in the development of shoulder pain, ${ }^{45}$ and many studies have been conducted in various occupational settings. The cause of shoulder pain has been considered in several reviews, ${ }^{4-11}$ but most of these either did not consider shoulder pain specifically or did not use systematic methods for the selection of papers, assessment of methodological quality, or data extraction and analysis. An elegantly conducted meta-analysis published in 1991 summarised the results of workplace ergonomic risk factors for neck and upper limb pain. ${ }^{7}$ Unfortunately, only three studies, not specifically aimed at shoulder pain, met the relatively strict selection criteria and were included in this meta-analysis.

Since 1990 many additional papers on risk factors for shoulder pain have been published. The objective of this paper was to summarise the available evidence on occupational risk factors related to physical load and psychosocial factors, and to identify methodological shortcomings to set priorities for future research on the cause of shoulder pain. 


\section{Methods}

SEARCH STRATEGY

Publications were retrieved by a computerised search of Medline (1966 to September 1998), Embase (1983 to September 1998), Psychlit (1966 to September 1998) and Cinahl (1982 to September 1998), with the following keywords (MeSH headings and text words): shoulder, shoulder joint, pain, cross-sectional, cohort, case-control, determinant, predictor, risk factor, etiology, aetiology, and causative. The references of all identified relevant studies, including reviews and meta-analyses, were hand searched for additional potentially relevant publications. All publications published until September 1998 were eligible for inclusion in the review.

Two reviewers (DAWMW and ET) independently applied the selection criteria to the abstracts of the publications retrieved by this search strategy. Full papers were retrieved if the abstract provided insufficient information to enable selection. During a consensus meeting any disagreements about selection were resolved.

\section{SELECTION CRITERIA}

Studies were included in the review if the following conditions were met: $(a)$ the study was a cross sectional, case-control, or prospective cohort study; $(b)$ the paper was a full report published in English in a peer reviewed journal; (c) information was presented on physical load or psychosocial risk factors at work; (d) exposures were assessed with standardised observational methods or standardised interviews or questionnaires; (e) shoulder pain was self reported or confirmed by physical exam- ination; $(f)$ in studies on combined neck and upper limb pain or other pain symptoms, data on shoulder pain were presented separately. Excluded were studies on acute injuries due to trauma or sports injuries, studies that estimated exposure from job titles only, letters, and abstracts.

\section{OUALITY ASSESSMENT}

Differences in methodological quality across studies can indicate that the results of some studies are more likely to be affected by bias than others. It is important, therefore, to take the quality of a study into account when evaluating the potential causal distribution of risk factors. Two reviewers (DAWMW and ET) independently assessed the quality of each study. We used a modified version of the checklists for quality appraisal designed by Ariëns $e t a l^{12}$ and Hoogendoorn et al. ${ }^{13}$ Slightly different checklists were used for the quality assessment of cross sectional studies (17 items), case-control studies (21 items), and prospective cohort studies (19 items). Each item was scored as positive, negative (potential bias), or don't know (unclear) if the paper provided insufficient information on a specific item. A summary of the checklists and the conditions for scoring either positive or negative are presented in table 1 .

If the design included only an evaluation of either physical load or the psychosocial work environment, the studies were scored for the evaluated exposures; the items referring to the other dimension were scored as not applicable. Disagreements between the reviewers on individual items were identified and solved during a consensus meeting. Subsequently, method

Table 1 Standardised checklist for the assessment of methodological quality of cross sectional studies (CS), case-control studies (CC), and prospective cohort studies (PC)

Study objective

Positive if a specific, clearly stated objective is described

Study population

2 Positive if the main features of the study population are described (sampling frame and distribution of the population by age and sex)

Positive if cases and controls are drawn from the same population and a clear definition of cases and controls was stated, and if people with shoulder pain in the past 3 months are excluded from the controls

4 Positive if the participation rate is $\geqslant 80 \%$ or if participation rate is $60 \%-80 \%$ and non-response is not selective (data presented)

5 Positive if the response at main moment of follow up is $\geqslant 80 \%$ or if the non-response is not selective (data presented)

Exposure assessment, physical load at work (if not included in the design, not applicable (NA))

6 Positive if data are collected and presented about physical load at work

$7 \quad$ Method for measuring physical load at work: direct measurement and observation $(+)$, interview or questionnaire only $(-)$

Positive if more than one dimension of physical load is assessed: duration, frequency, or amplitude

Exposure assessment, psychosocial factors at work (if not included in the design, NA)

9 Positive if data are collected and presented about psychosocial factors at work

10 Positive if more than one aspect of psychosocial factors is assessed: work demands, job control, social support

Exposure assessment, other

11 Positive if data are collected and presented about physical or psychosocial exposure during leisure time

12 Positive if data are collected and presented about occupational exposure in the past

13 Positive if data are collected and presented about a history of shoulder disorders

14 Positive if exposure is measured in an identical manner in cases and controls

15 Positive if the exposure assessment is blinded to disease status

16 Positive if the exposure is assessed at a time before the occurrence of the disease

Outcome assessment

17 Positive if data were collected for $\geqslant 1$ year

18 Positive if data were collected at least every 3 months

19 Method for assessing shoulder pain: physical examination blinded to exposure status (+), self reported: specific questions relating to shoulder disability or use of manikin $(+)$, single question $(-)$

20 Positive if incident cases are used (prospective enrolment)

Analysis and data presentation

21 Positive if the appropriate statistical model is used (univariate or multivariate model)

22 Positive if a logistic regression model is used in the case of an unmatched case-control study and a conditional logistic regression model in the case of a matched case-control study

23 Positive if measures of association are presented (OR/RR), including $95 \%$ CIs and numbers in the analysis (totals)

24 Positive if the analysis is controlled for confounding or effect modification is studied

25 Positive if the number of cases in the multivariate analysis is at least 10 times the number of independent variables in the analysis (final model)
$\mathrm{CS} / \mathrm{CC} / \mathrm{PC}$

$\mathrm{CS} / \mathrm{CC} / \mathrm{PC}$

$\mathrm{CS} / \mathrm{CC} / \mathrm{PC}$ PC

$\mathrm{CS} / \mathrm{CC} / \mathrm{PC}$ $\mathrm{CS} / \mathrm{CC} / \mathrm{PC}$ $\mathrm{CS} / \mathrm{CC} / \mathrm{PC}$

$\mathrm{CS} / \mathrm{CC} / \mathrm{PC}$ $\mathrm{CS} / \mathrm{CC} / \mathrm{PC}$

$\mathrm{CS} / \mathrm{CC} / \mathrm{PC}$ $\mathrm{CS} / \mathrm{CC} / \mathrm{PC}$ $\mathrm{CS} / \mathrm{CC} / \mathrm{PC}$ CC CS/CC CC

PC $\mathrm{PC} / \mathrm{CC} / \mathrm{PC}$ $\mathrm{CC}$ $\mathrm{CC}$ $\mathrm{CS} / \mathrm{PC}$ CC 


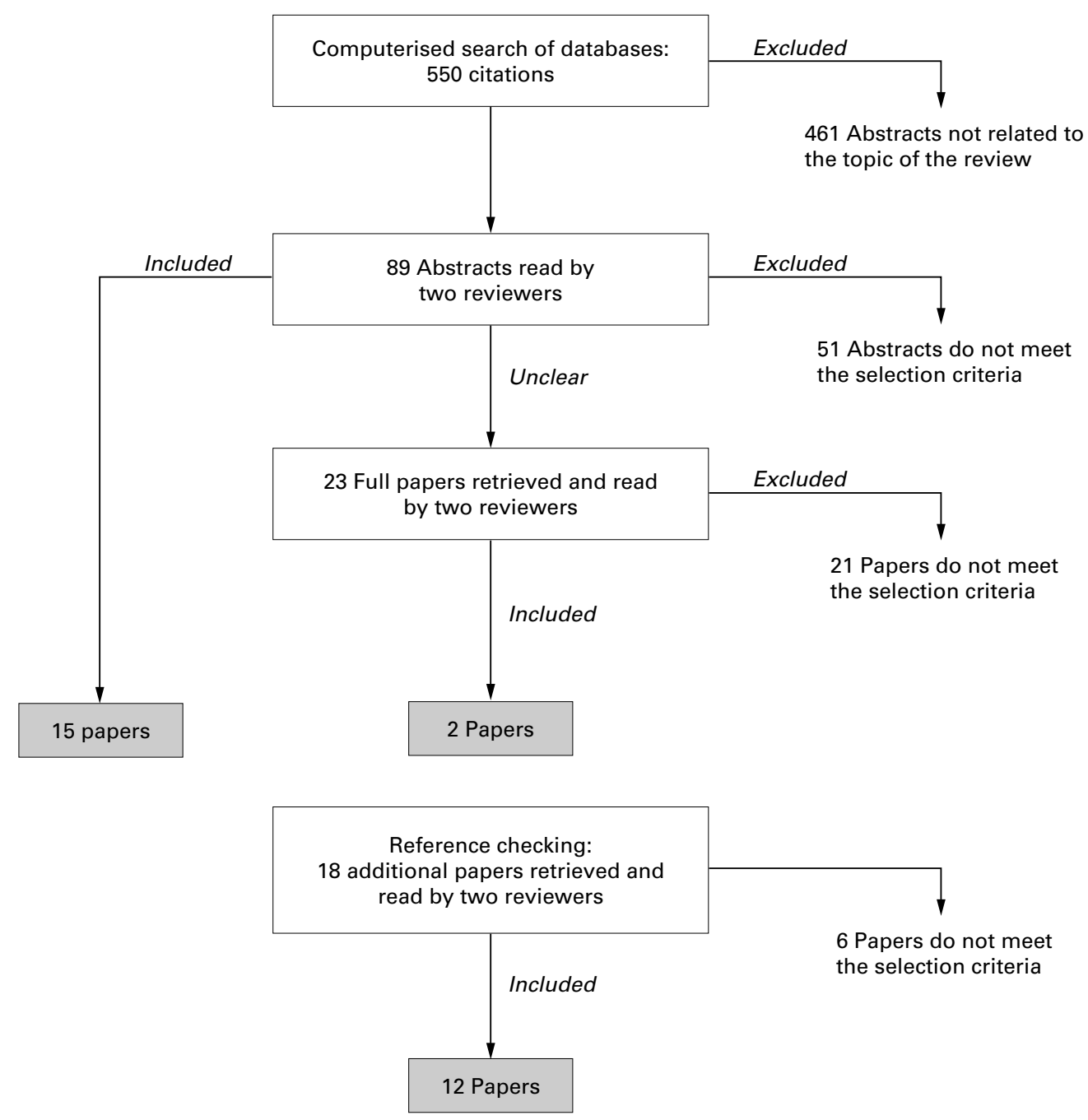

Flow diagram of papers accepted and rejected by the two reviewers during the selection procedure.

scores were computed as the total number of positively scored items over the total number of applicable items. The studies were ranked according to their total score for methodological quality (as a percentage of the maximum attainable score).

DATA EXTRACTION AND ANALYSIS

For each study we extracted details on the study population (setting, sampling frame, sample size, response rate, age, and sex), exposure to risk factors (physical load and the psychosocial work environment), and outcome (definition of shoulder pain, and the association with exposure variables in terms of relative risks or odds ratios (ORs)). Pooled risk estimates were calculated only if there was homogeneity across studies for exposure variables (type of risk factor and method of assessment) and outcome (similar case definition of shoulder pain). A random effects model was used to allow for additional heterogeneity across studies. ${ }^{14} 15$

STRENGTH OF EVIDENCE

In epidemiological studies it is not possible to establish a direct causal link between risk factors and shoulder pain. If the assocation is established in studies of relatively high quality, the strength of evidence for causality of a risk factor can be evaluated by summarising the available evidence about the following criteria: temporal relation, consistency of the association across studies, strength of the association, and biological plausibility of the association. ${ }^{791016}$ Although none of these criteria can bring indisputable evidence for or against the cause-effect hypothesis and none can be required as an essential condition, ${ }^{16}$ they do facilitate a systematic evaluation of the literature. We defined the following (arbitrary) decision rules to summarise the strength of evidence for each risk factor of shoulder pain.

\section{Temporal relation}

Prospective cohort studies provide stronger evidence for causality than case-control or cross sectional studies.

\section{Relatively high methodological quality}

Conclusions will be based on studies with a method score equal to or higher than the median method score of all publications in the review. 
Table 2 Results of the quality assessment of cross sectional studies and case-control studies

\begin{tabular}{|c|c|c|c|c|c|c|c|c|c|c|c|c|c|c|c|c|c|c|c|c|c|c|c|c|c|}
\hline \multirow{2}{*}{$\begin{array}{l}\text { Study } \\
\text { referencet }\end{array}$} & \multicolumn{22}{|c|}{ Methodological items* } & \multirow[b]{2}{*}{ Disagreements } & \multirow{2}{*}{$\begin{array}{l}\text { Method } \\
\text { score }\end{array}$} & \multirow{2}{*}{ (\%) } \\
\hline & 1 & 2 & 3 & 4 & 6 & 7 & 8 & 9 & 10 & 11 & 12 & 13 & 14 & 15 & 16 & 19 & 20 & 21 & 22 & 23 & 24 & 25 & & & \\
\hline \multicolumn{26}{|c|}{ Cross sectional studies } \\
\hline 17 & + & + & & - & + & + & + & + & + & + & - & + & & ? & & + & & + & & + & + & + & $11,12,13$ & $14 / 17$ & 82 \\
\hline 18 & + & + & & ? & + & + & + & NA & NA & - & + & + & & ? & & + & & + & & - & + & + & $2,8,12,13,23$ & $11 / 15$ & 73 \\
\hline 19 & + & + & & - & + & - & + & NA & NA & + & - & + & & ? & & + & & + & & + & + & + & 8,12 & $11 / 15$ & 73 \\
\hline 20 & + & ? & & + & + & + & + & + & + & - & + & - & & ? & & + & & + & & ? & + & + & - & $12 / 17$ & 71 \\
\hline 21 & + & + & & + & + & - & - & + & + & + & - & - & & ? & & + & & + & & + & + & + & 6 & $12 / 17$ & 71 \\
\hline 22 & + & + & & + & + & - & - & + & + & - & - & + & & ? & & + & & + & & + & + & + & 6,12 & $12 / 17$ & 71 \\
\hline 23 & + & + & & + & + & - & + & NA & NA & + & $?$ & $?$ & & ? & & + & & $?$ & & + & + & + & $12,13,21$ & $10 / 15$ & 67 \\
\hline 24 & + & + & & + & + & + & - & + & $?$ & - & - & - & & ? & & + & & + & & + & + & + & $1,12,15,19$ & $11 / 17$ & 65 \\
\hline 25 & + & + & & + & + & - & + & + & + & $?$ & - & - & & ? & & + & & + & & + & - & + & $11,12,24$ & $11 / 17$ & 65 \\
\hline 26 & + & $?$ & & - & + & - & + & + & + & - & - & - & & - & & + & & + & & + & + & + & $2,4,23$ & $11 / 17$ & 65 \\
\hline 27 & + & + & & - & + & - & - & + & + & + & - & - & & $?$ & & + & & + & & + & + & + & 4 & $11 / 17$ & 65 \\
\hline 28 & + & + & & + & + & - & - & NA & NA & $?$ & - & - & & + & & + & & + & & + & + & $?$ & $1,11,25$ & $9 / 15$ & 60 \\
\hline 29 & + & + & & + & + & - & - & NA & NA & - & + & - & & $?$ & & - & & + & & + & + & + & - & $9 / 15$ & 60 \\
\hline 30 & + & + & & + & + & + & + & + & - & + & + & - & & ? & & + & & - & & - & - & - & $11-13,23-25$ & $10 / 17$ & 59 \\
\hline 31 & + & - & & + & + & - & + & + & + & - & - & - & & - & & + & & - & & - & + & + & 2 & $9 / 17$ & 53 \\
\hline 32 & + & + & & + & + & - & - & + & + & - & - & - & & $?$ & & + & & + & & + & - & $?$ & 12,21 & $9 / 17$ & 53 \\
\hline 33 & + & + & & + & + & - & - & NA & NA & - & - & - & & ? & & - & & + & & + & + & + & 8 & $8 / 15$ & 53 \\
\hline $34 / 35$ & + & + & & $?$ & + & - & - & + & - & ? & + & - & & ? & & $?$ & & + & & - & + & + & $6,11,12,19,24$ & $8 / 17$ & 47 \\
\hline 36 & + & + & & + & + & $?$ & + & $?$ & - & + & - & - & & ? & & + & & - & & - & $?$ & + & $2,7,21$ & $8 / 17$ & 47 \\
\hline 37 & + & + & & $?$ & + & + & + & + & + & - & - & ? & & ? & & + & & - & & - & - & - & $4,7,8,13,15$ & $8 / 17$ & 47 \\
\hline 38 & + & ? & & - & + & - & - & + & + & $?$ & ? & ? & & ? & & + & & + & & + & + & - & $7,8,11,15$ & $8 / 17$ & 47 \\
\hline 39 & + & + & & + & + & + & + & NA & NA & + & $?$ & - & & $?$ & & - & & - & & - & $?$ & $?$ & $19,21,24$ & $7 / 15$ & 47 \\
\hline 40 & + & + & & $?$ & + & - & - & NA & NA & - & - & - & & ? & & + & & + & & - & + & + & $2,19,25$ & $7 / 15$ & 47 \\
\hline 41 & + & + & & + & + & - & - & NA & NA & - & - & - & & $?$ & & + & & - & & - & + & + & 21,25 & $7 / 15$ & 47 \\
\hline 42 & + & + & & $?$ & + & - & - & NA & NA & - & $?$ & - & & ? & & - & & + & & + & + & + & 2,4 & $7 / 15$ & 47 \\
\hline 43 & + & + & & + & NA & NA & NA & + & + & - & ? & - & & ? & & + & & $?$ & & $?$ & - & $?$ & 23,24 & $6 / 14$ & 43 \\
\hline \multicolumn{26}{|c|}{ Case-control studies } \\
\hline 44 & + & + & + & + & + & - & + & NA & NA & + & $?$ & ? & + & - & $?$ & + & + & & + & + & + & + & $2,3,13,15,16$ & $14 / 19$ & 74 \\
\hline 45 & + & $?$ & $?$ & $?$ & + & - & - & + & - & - & + & ? & + & $?$ & + & + & - & & $?$ & + & + & $?$ & $2,4,22,25$ & $9 / 21$ & 43 \\
\hline 46 & $?$ & $?$ & + & $?$ & + & $?$ & + & NA & NA & - & + & - & + & ? & - & + & + & & - & - & - & $?$ & 8,12 & $7 / 19$ & 37 \\
\hline
\end{tabular}

«Enumeration of the quality items as in table 1. Items are scored as positive scores (+), negative (-), or unclear (insufficient information) (?).

$\dagger$ The studies are ranked according to their methods scores. Equally ranked studies are alphabetically ordered according to the first author's name.

$\mathrm{NA}=$ not applicable.

Strong association

The association between the risk factor at issue and the occurrence of shoulder pain is strong (OR or risk ratio (RR) >2.0), significant $(p<0.05)$, or a dose-response relation is established.

Consistent results

At least $75 \%$ of the studies report a strong association for the risk factor at issue.

\section{Results}

SEARCH STRATEGY

The search of the computerised databases identified a total of 550 citations. After checking for doubles, and excluding studies clearly not related to the objective of our review-for example, studies on shoulder distocia in newborn infants, traumatic injuries, pain after surgery, or complications after stroke-89 abstracts were considered in the selection procedure. Screening of the references of all relevant papers resulted in 18 additional studies. The flow diagram in the figure describes the number of abstracts accepted and rejected by the two reviewers during the selection procedure.

A total of 29 studies were finally included in the review. ${ }^{17-46}$ Of the 107 papers submitted to the selection procedure 78 were excluded, often for more than one reason: studies reporting on combined neck-shoulder pain (38 papers), no evaluation of occupational risk factors (nine papers), assessment of exposure by job title only (eight papers), no separate presentation of results on shoulder pain (seven papers), literature review (13 papers), or various other reasons (20 papers).
METHODOLOGICAL QUALITY

Only one out of the 29 studies in the review (described by two papers) was designed as a prospective cohort study. ${ }^{34}{ }^{35}$ However, the occupational exposures were evaluated at the same time as the occurrence of shoulder pain, and consequently, the study was included in our review as a cross sectional study.

The results of the quality appraisal are presented in table 2, separately for cross sectional $(n=26)$ and case-control studies $(n=3)$. For each study, the table shows the score for each individual item, the items on which the reviewers initially disagreed, and the total method score. The studies are ranked according to their total score, and in cases of equal ranking, in alphabetical order of the first author's surname. The reviewers agreed in 400 out of 480 scored items (83.3\%). Disagreements often were about items 12 (assessment of occupational exposure in the past) and 13 (assessment of shoulder pain in the past). All disagreements were resolved during a consensus meeting. The median (range) method score of the cross sectional studies was $60 \%$ $(43 \%-83 \%)$. This score of $60 \%$ was used as a cut off point to identify studies of relatively high methodological quality. The three casecontrol studies scored $37 \%, 43 \%$, and $74 \%$, respectively.

The following items were rated as negative in most studies: methods used for exposure assessment (items 7 and 8); assessment of important potential confounders (exposure during leisure time, item 11, or occupational exposure in the past, item 12); and presentation of data on the history of shoulder pain (item 13). Information about methods to blind 
assessment of exposure to the disease status was usually not provided (item 15). Only one study was assigned a positive score for this item, indicating an attempt to prevent information bias. ${ }^{28}$

\section{STUDY CHARACTERISTICS}

Table 3 presents a summary of the study characteristics, including the case definition, sampling frame, study size, and risk estimates, separately for cross sectional and case-control studies. The table presents multivariate risk estimates together with their $95 \%$ confidence interval $(95 \% \mathrm{CI})$, and provides information on adjustments for confounding of the final statistical analysis if reported by the authors. To limit the size of the tables, only significant associations and effect estimates with relative risks or ORs $>2.0$ or $<0.5$ are presented. Additional information on the design and results of each study can be obtained from the corresponding author.

Table 3 shows that there was a wide variety across papers of study settings, exposures measured, and assessment of shoulder pain. This hampered the possibilities for statistical pooling of results, and necessitated a qualitative summary of the results. Moreover, the presentation of results on associations between exposures and the occurrence of shoulder pain was often inadequate. Some studies only presented levels of significance, without presenting estimates of risk. Adjustments for confounding were performed by several studies, but varied from stratification by sex only to the use of a multivariate model adjusting for all potential confounders. In some papers it was unclear which confounders had been included in the final model. This complicated the interpretation of the magnitude of the reported associations and ruled out sensible statistical pooling.

\section{PHYSICAL LOAD}

The wide variety of physical work load factors were grouped into the following categories: heavy physical load (14 studies); awkward postures, including twisted postures, working with forward flexed trunk, and working with arms above shoulder level (13 studies); repetitive movements (eight studies); conducting the same activity for a prolonged period - such as typing or driving a car-(five studies); vibration (six studies); and duration of employment (10 studies). Table 4 gives a qualitative summary of the available evidence for these categories. The table presents the number of studies on each risk factor, the proportion of studies reporting positive associations (consistency of findings), a summary of the strength of the association, and the median method score for studies that either did or did not report positive findings.

As nearly all studies adopted cross sectional designs, a temporal relation between occupational risk factors and shoulder pain has, as yet, not been established. It must also be noted that some risk factors were evaluated by a few studies. In studies with relatively high method scores (method score $\geqslant 60 \%$ ), consistent positive associations (at least $75 \%$ positive findings) were reported for repetitive movements, ${ }^{17} 2644$ vibration, ${ }^{1823}$ and duration of employment. ${ }^{192224}$ Working in awkward postures and conducting similar work for a prolonged period (typing) were also found to be associated with shoulder pain in most studies, but mainly in studies with relatively low method scores.

The reported strength of the associations varied widely (ORs 1.4-46), and was difficult to interpret due to the previously mentioned variation in definition and assessment of exposures, outcomes, and methods used for analysis and presentation of data. The quality of the available evidence was not impressive for most risk factors, with median method scores for positive findings between $47 \%$ and $62 \%$. Noteworthy is the finding that for heavy physical load, awkward postures, and for conducting similar activities for long periods, the methodological quality was higher for studies that were unable to confirm the association than for the studies that did report positive results.

Many studies evaluated additional, more specific job characteristics that do not fit within the categories mentioned already-for example bricklaying and rock blasting in the construction industry, ${ }^{23}$ type of ward in nursing, ${ }^{21}$ scaling in dental hygienists, ${ }^{19}$ or lancing (cleaning air vents in the furnace of a pulp and paper mill). ${ }^{38}$ These factors rarely showed a positive association with shoulder pain. Finally, the influence of the work environment was evaluated by Pope et al. ${ }^{45}$ Hot, cold, damp, and noisy conditions seemed to be associated with an increased occurrence of shoulder pain (range of RR 2.2-6.4).

PSYCHOSOCIAL WORK ENVIRONMENT

Psychosocial risk factors may be related to psychological demands at work (mental stress, job pressure, 14 studies); control at work (participation in job decision making, influence on work schedule, 11 studies); social support at work (from coworkers and supervisors, 12 studies); and job satisfaction or stimulus at work (work content, monotonous work, career prospects, 12 studies). In the last category we also included the concept investigated by Hales et $a l^{25}$; fear of being replaced by computers.

Nearly all studies that included an assessment of the psychosocial work environment reported positive findings for at least one specific risk factor. The summary of evidence presented in table 4, however, shows that consistent positive findings (at least $75 \%$ positive outcomes) were not found for any of the four categories. The reported strength of the associations seems to be moderate, with the range of ORs 1.3-2.0 for most associations. Larger risk estimates were reported for poor job control, ${ }^{17}$ and for job dissatisfaction. ${ }^{25}{ }^{43}$ The quality of the available evidence seems to be fairly good for job control, with a median method score of $68 \%$. However, median method scores were also relatively high for studies that were unable to show a positive association between shoulder pain and psychological work demands, job control, and social support. Noteworthy may be the fact that three 
Table 3 Design and results of cross sectional and case-control studies on occupational risk factors for shoulder pain

\begin{tabular}{|c|c|c|c|c|c|}
\hline \multirow{2}{*}{$\begin{array}{l}\text { Study } \\
\text { reference }\end{array}$} & \multirow{2}{*}{$\begin{array}{l}\text { Score } \\
(\%)\end{array}$} & \multirow[b]{2}{*}{ Case definition } & \multicolumn{2}{|l|}{ Study population } & \multirow{2}{*}{$\begin{array}{l}\text { Positive findings }{ }^{\star} \\
(p<0.05 \text { or ORs }>2.0 \text { or }<0.5)\end{array}$} \\
\hline & & & Sampling frame & Sample size & \\
\hline \multicolumn{6}{|c|}{ Design and results of cross sectional studies on occupational risk factors for shoulder pain } \\
\hline 17 & 82 & $\begin{array}{l}\text { Shoulder pain }>1 / \text { month or } \\
\text { during }>1 \text { week in the past } \\
\text { year }(\mathrm{Q}+\mathrm{Ex}) \dagger\end{array}$ & $\begin{array}{l}\text { Male employees from selected } \\
\text { job groups in aluminium } \\
\text { smelter (USA) }\end{array}$ & $\begin{array}{l}62 / 96(\mathrm{R}=65 \%) \\
36 / 64(\mathrm{R}=56 \%) \\
9 / 21(\mathrm{R}=33 \%)\end{array}$ & $\begin{array}{l}\text { LR (OR, adjusted for age, smoking, sport or hobbies) } \\
\text { good health, } 0.4(0.1 \text { to } 0.9) \text {; low decision latitude, } 4.0 \\
(0.8 \text { to } 19) ; \\
\text { years of forearm twisting, } 46(3.8 \text { to } 550)\end{array}$ \\
\hline 18 & 73 & $\begin{array}{l}\text { Shoulder pain or stiffness } \\
\text { during the past year }(\mathrm{NQ}) \dagger\end{array}$ & $\begin{array}{l}\text { Riveters and control manual } \\
\text { workers (aircraft industry, The } \\
\text { Netherlands) }\end{array}$ & $\begin{array}{l}147 / 194(\mathrm{R}=76 \%) \\
125 / 194(\mathrm{R}=64 \%)\end{array}$ & $\begin{array}{l}\mathrm{LR}(\mathrm{OR} \text { adjusted for age) } \\
\text { per year riveting, } \beta=0.041, \mathrm{OR}=1.04(0.05<\mathrm{p}<0.10)\end{array}$ \\
\hline 19 & 73 & $\begin{array}{l}\text { Shoulder symptoms during } \\
\text { the past year (NQ) }\end{array}$ & $\begin{array}{l}\text { All members dental hygienist } \\
\text { association (DH), plus dental } \\
\text { assistents (DA) (Canada) }\end{array}$ & $\begin{array}{l}\text { DH, } 1066 / 2142 \\
(\mathrm{R}=50 \%) \\
\mathrm{DA}, 154 / 305 \\
(\mathrm{R}=51 \%)\end{array}$ & $\begin{array}{l}\text { LR (OR adjusted for age, history of shoulder pain) } \\
\text { no general practice, } 1.8(1.2 \text { to } 2.8) \text {, } \\
5-6 \text { days/week } v<3,1.8(1.1 \text { to } 3.2) \\
\text { time with rotated body; } 61 \%-80 \% v 1 \%-20 \%, 2.8(1.9 \\
\text { to } 4.3) ; 81 \%-100 \%, 3.1(1.9 \text { to } 4.9) \\
\text { years in practice } 1-14 \mathrm{y}, 3.9 \text { (1.9 to } 7.9) ;>14 \mathrm{y}, 2.1 \\
(0.9 \text { to } 5.1)\end{array}$ \\
\hline 20 & 71 & $\begin{array}{l}\text { Pain for at least a few hours } \\
\text { during the past year (NQ) } \dagger\end{array}$ & $\begin{array}{l}\text { All workers in a Dutch tank } \\
\text { terminal company }\end{array}$ & $161 / 172(\mathrm{R}=94 \%)$ & $\begin{array}{l}\text { LR (OR adjusted for age) } \\
\text { heavy physical load previous jobs, } 3.6 \text { (1.3 to } 9.8 \text { ) }\end{array}$ \\
\hline 21 & 71 & $\begin{array}{l}\text { Shoulder symptoms (NQ, } \\
0-10 \text { scale) severe, }>5 \text { points }\end{array}$ & $\begin{array}{l}\text { All female nursing personnel } \\
\text { Swedish hospital }\end{array}$ & $821(\mathrm{R}=100 \%)$ & $\begin{array}{l}\text { LR (OR adjusted for age), } \\
\text { low fitness, } 1.8 \text { (1.3 to } 2.5) \text {; low job control, } 1.7 \text { (1.1 to } \\
2.7 \text { ) } \\
\text { for severe symptoms, } \\
\text { low fitness, } 2.2 \text { ( } 1.5 \text { to } 3.4) \text {; high work demand, } 1.7 \\
(1.1 \text { to } 2.6)\end{array}$ \\
\hline 22 & 71 & $\begin{array}{l}\text { Shoulder pain }>1 / \text { week or } \\
\text { during }>1 \text { week in the past } \\
\text { year }(Q) \cdot \dagger\end{array}$ & $\begin{array}{l}\text { Random sample of active } \\
\text { carpenters (USA) }\end{array}$ & $522 / 627(\mathrm{R}=83 \%)$ & $\begin{array}{l}\text { LR (OR adjusted for age, smoking, previous health), } \\
10-20 \text { y employment, } 2.3 \text { (1.0 to 5.4); } \\
>20 \text { y employment, } 3.2(1.1 \text { to } 8.9) \\
\text { minimal schedule influence, } 1.9(1.1-3.2)\end{array}$ \\
\hline 23 & 67 & Shoulder tendinitis (Ex) & $\begin{array}{l}\text { Random selection of male } \\
\text { construction industry workers } \\
\text { (Sweden) }\end{array}$ & $\begin{array}{l}\text { 54/75 Brick layers } \\
\text { 55/75 Rock blasters } \\
98 / 110 \text { Foremen } \\
(\mathrm{R}=80 \%)\end{array}$ & $\begin{array}{l}\text { LR (OR adjusted for age, dexterity, sport activities, } \\
\text { smoking), } \\
\text { vibration (highest } v \text { lowest category), } 2.6 \text { (0.6 to } 12.5) \\
\text { left side } \\
\text { rock } v \text { foremen, } 3.3 \text { (1.2 to } 9.2) \text { left; } 1.7 \text { ( } 0.7 \text { to } 4.2) \\
\text { right side } \\
\text { brick } v \text { foremen, } 0.4 \text { (0.2 to } 1.3 \text { ) right; insufficient cases } \\
\text { left side }\end{array}$ \\
\hline 24 & 65 & $\begin{array}{l}\text { At least moderate shoulder } \\
\text { symptoms }>1 / \text { month or } \\
\text { during }>1 \text { week in the past } \\
\text { year }(Q) \dagger\end{array}$ & $\begin{array}{l}\text { Random selection of full time } \\
\text { newspaper employees (USA) }\end{array}$ & $894 / 973(\mathrm{R}=92 \%)$ & $\begin{array}{l}\text { LR (OR adjusted for sex and race) } \\
\text { lack of participation in job decision making, } 1.6 \text { (1.2 to } \\
2.1 \text { ) } \\
\text { years employed, } 1.4(1.2 \text { to } 1.8) \\
\text { increased job pressure, } 1.5 \text { (1.0 to } 2.2)\end{array}$ \\
\hline 25 & 65 & $\begin{array}{l}\text { Work related specific } \\
\text { shoulder disorders (Ex) }\end{array}$ & $\begin{array}{l}\text { Telecommunication company, } \\
\text { visual display terminal users } \\
\text { (USA) }\end{array}$ & $533 / 573(\mathrm{R}=93 \%)$ & $\begin{array}{l}\text { LR (OR) } \\
\text { fear of being replaced by computers, } 2.7 \text { (1.3 to } 5.8) \\
\text { arising from chair, } 1.9 \text { ( } 1.2 \text { to } 3.2)\end{array}$ \\
\hline 26 & 65 & $\begin{array}{l}\text { Work related shoulder } \\
\text { symptoms during the past } \\
\text { year (NQ) }\end{array}$ & $\begin{array}{l}\text { All workers in one municipal } \\
\text { district, home care wokers and } \\
\text { other employees (Sweden) }\end{array}$ & $1020 / 1330(\mathrm{R}=77 \%)$ & $\begin{array}{l}\text { LR (univariate RR adjusted for age) } \\
\text { stimulus from work, } 1.3 \text { (1.0 to } 1.7) \text {; flexed trunk, } 1.6 \\
(1.2 \text { to } 2.1) \text {; } \\
\text { work demands, } 1.5 \text { (1.2 to } 2.0) \ddagger \text {; twisted postures, } 1.6 \\
(1.1 \text { to } 2.2) \text {; } \\
\text { lifting, } 1.7 \text { (1.2 to } 2.4) \ddagger \text {; arms above shoulders, } 1.5(1.2 \\
\text { to } 1.9) \text {; } \\
\text { repetitive movements, } 1.5 \text { (1.1 to } 1.9) \ddagger \\
\text { ( } \ddagger \text { also significant in multivariate model) }\end{array}$ \\
\hline 27 & 65 & $\begin{array}{l}\text { Shoulder pain during the } \\
\text { past year (NQ) }\end{array}$ & $\begin{array}{l}\text { Random } 8 \% \text { sample of active } \\
\text { salespeople (Denmark) }\end{array}$ & $\begin{array}{l}\mathrm{n}=1306 / 1991 \\
(\mathrm{R}=66 \%)\end{array}$ & $\begin{array}{l}\text { LR (OR, PPR also presented, adjusted for age, sex, and } \\
\text { smoking) } \\
\geqslant 30 v<10 \mathrm{~h} / \text { week in car, } 1.6(1.0 \text { to } 2.7) \\
\text { high work demands, } 1.5(1.1 \text { to } 2.1) ; \\
\text { uncertainty employment, } 1.5 \text { (1.0 to } 2.3)\end{array}$ \\
\hline 28 & 60 & $\begin{array}{l}\text { Subacromial shoulder pain } \\
\text { (Ex) }\end{array}$ & $\begin{array}{l}\text { Survey of randomly selected } \\
50-70 \text { year olds (Sweden) }\end{array}$ & $\begin{array}{l}445 / 552(\mathrm{R}=81 \%) \\
+57(\text { selected })\end{array}$ & $\begin{array}{l}\text { LR (OR adjusted for ?), } \\
\text { self-rated heavy workload, } 5.4 \text { ( } 3.4 \text { to } 8.6 \text { ) }\end{array}$ \\
\hline 29 & 60 & $\begin{array}{l}\text { Shoulder pain or stiffness } \\
\text { during the past month }(\mathrm{Q})\end{array}$ & $\begin{array}{l}\text { Systematic sample of retired } \\
\text { post office workers (UK) }\end{array}$ & $3920 / 5042(\mathrm{R}=78 \%)$ & $\begin{array}{l}\mathrm{LR}(\mathrm{RR} \text {, adjusted for sex) } \\
\text { working above shoulder level, } 1-20 \mathrm{y}(>1 \mathrm{~h} / \text { day }), 1.4 \\
(1.2 \text { to } 1.6) \\
>20 \mathrm{y}(>1 \mathrm{~h} \text { /day), } 1.4(1.2 \text { to } 1.6)\end{array}$ \\
\hline 30 & 59 & $\begin{array}{l}\text { Shoulder symptoms during } \\
\text { the past year }(\mathrm{Q}+\mathrm{Ex}) \text {. }\end{array}$ & $\begin{array}{l}\text { All female employees of five } \\
\text { assembly departments } \\
\text { electronic factory (Sweden) }\end{array}$ & $106 / 138(\mathrm{R}=77 \%)$ & $\begin{array}{l}\text { Multiple regression (only } \mathrm{R}^{2} \text { presented) } \\
\text { employment }(\mathrm{y}, \mathrm{p}<0.05) ; \text { less upper arm flexions } \\
(\mathrm{p}<0.05) \text {; } \\
\text { arm abducted } 0-30^{\circ} \text { over long periods }(\mathrm{p}<0.05)\end{array}$ \\
\hline 31 & 53 & $\begin{array}{l}\text { Work related shoulder } \\
\text { symptoms during the past } \\
\text { year (NQ) } †\end{array}$ & $\begin{array}{l}\text { Random selection / all workers } \\
\text { in eight metal industry } \\
\text { companies (Sweden) }\end{array}$ & $\begin{array}{l}241 \text { blue, } 209 \text { white } \\
\text { collar, } R= \pm 90 \%\end{array}$ & $\begin{array}{l}\text { Multivariate regression (partial correlations R adjusted } \\
\text { for age and sex), blue or white collar workers } \\
\text { low job control, } 0.18 \text { / } 0.17 \text {; poor supervisor climate, } \\
0.16 / 0.20 \text {; } \\
\text { low stimulus from work, } 0.26 \text { / } 0.22 \text {; high psychological } \\
\text { demands, } 0.27 / 0.21 ; \\
\text { extreme work postures, } 0.14 \text { / NS; twisted postures, }- \text { / } \\
0.16 \text {; } \\
\text { light materials handling, ns / } 0.18 \text {; repetitive } \\
\text { movements, } 0.15 / 0.32 \text {; } \\
\text { poor relation fellow workers ns / } 0.24\end{array}$ \\
\hline 32 & 53 & $\begin{array}{l}\text { Frequent shoulder pain } \\
\text { during the past year (NQ) }\end{array}$ & $\begin{array}{l}\text { All medical secretaries and } \\
\text { office personnel in a hospital } \\
\text { (Sweden) }\end{array}$ & $420 / 438(\mathrm{R}=96 \%)$ & $\begin{array}{l}\text { Univariate analysis }(\mathrm{OR}) \\
>5 \mathrm{y} \text { employed (stratified for age), } 1.9(1.1 \text { to } 3.4) \\
>5 \mathrm{~h} \text { with machines, } 1.9(1.2 \text { to } 3.0) \\
\chi^{2}(4) \text { test (no odds ratios presented), } \\
\text { unfriendly spirit of cooperation, } \mathrm{p}=0.03 \text {; given too } \\
\text { much work } \\
\mathrm{p}=0.05, \text { no influence on work conditions, } \mathrm{p}=0.003\end{array}$ \\
\hline
\end{tabular}


Table 3-Continued

\begin{tabular}{|c|c|c|c|c|c|}
\hline \multirow{2}{*}{$\begin{array}{l}\text { Study } \\
\text { reference }\end{array}$} & \multirow{2}{*}{$\begin{array}{l}\text { Score } \\
(\%)\end{array}$} & \multirow[b]{2}{*}{ Case definition } & \multicolumn{2}{|l|}{ Study population } & \multirow{2}{*}{$\begin{array}{l}\text { Positive findings }{ }^{\star} \\
\text { (statistically significant or ORs }>2.0 \text { or }<0.5 \text { ) }\end{array}$} \\
\hline & & & Sampling frame & Sample size & \\
\hline 33 & 53 & $\begin{array}{l}\text { Shoulder discomfort or pain } \\
\text { ever. Onset during current } \\
\text { job (Q). }\end{array}$ & $\begin{array}{l}\text { All staff of six departments in a } \\
\text { bank, visual display unit users } \\
\text { (Hong Kong) }\end{array}$ & $121 / 151(\mathrm{R}=80 \%)$ & $\begin{array}{l}\text { LR (OR adjusted for age and sex) } \\
\text { fixed keyboard height, } 8.7 \text { ( } 2.4 \text { to } 32.4) \text {; bending back, } \\
5.1(1.5 \text { to } 7.2) \text {, frequent VDU user, } 18.9 \text { ( } 2.2 \text { to } \\
164.7)\end{array}$ \\
\hline 34,35 & 47 & $\begin{array}{l}\text { Shoulder pain }>24 \text { h some } \\
\text { time during the past month } \\
\text { (Q) }\end{array}$ & $\begin{array}{l}\text { Participants Malmö } \\
\text { longitudinal study, still residing } \\
\text { in Malmö after } 45 \text { years } \\
\text { (Sweden) }\end{array}$ & $575 / 830(\mathrm{R}=69 \%)$ & $\begin{array}{l}\mathrm{LR} \text { (adjusted for sex, intelligence) } \\
\text { job dissatisfaction, } \mathrm{p}<0.01 \text { (women) }\end{array}$ \\
\hline 36 & 47 & $\begin{array}{l}\text { Shoulder symptoms during } \\
\text { past? months (NQ), specific } \\
\text { shoulder disorders } \\
\text { (confirmed by Ex) }\end{array}$ & $\begin{array}{l}\text { All employees Volvo Flygmotor } \\
\text { (Sweden) }\end{array}$ & $2814 / 2933(\mathrm{R}=96 \%)$ & $\begin{array}{l}\text { Multivariate analysis (?) } \\
\text { high physical stress, } \mathrm{p}<0.05 \text {; vibrating tools, } \mathrm{p}<0.05 \text {; } \\
\text { mental stress at work, } \mathrm{p}<0.001\end{array}$ \\
\hline 37 & 47 & $\begin{array}{l}\text { Shoulder symptoms in the } \\
\text { past } 12 \text { months (NQ) }\end{array}$ & $\begin{array}{l}\text { All male workers in truck } \\
\text { assembly system (Sweden) }\end{array}$ & $28(\mathrm{R}=100 \%)$ & $\begin{array}{l}\text { Univariate analysis } \\
\text { repetitive movements }(\mathrm{p}<0.05) \text {; high physical load } \\
(\mathrm{p}<0.05) \text {; trunk flexions }(\mathrm{p}<0.05) \text {; high stress } \\
(\mathrm{p}<0.05) \text {; psychological work demands }(\mathrm{p}<0.05)\end{array}$ \\
\hline 38 & 47 & $\begin{array}{l}\text { Shoulder symptoms } \\
>1 / \text { month or during }>1 \text { week } \\
\text { in the past year. }(Q \\
\text { confirmed by Ex) } \dagger\end{array}$ & $\begin{array}{l}\text { Selected employees pulp and } \\
\text { paper mill (USA) }\end{array}$ & $40 / 58(\mathrm{R}=69 \%)$ & $\begin{array}{l}\text { LR (OR adjusted for age, hobbies }) \\
\text { job type, } 0.0(p=0.04) \text {; use of lance, } 317.3(p=0.05) \text {; } \\
\text { physical demand, } 1.1(p=0.05) \text {; use of wrench, } 6.7 \\
(p=0.28)\end{array}$ \\
\hline 39 & 47 & $\begin{array}{l}\text { Shoulder pain or stiffness } \\
\text { during the past month }(\mathrm{Q})\end{array}$ & $\begin{array}{l}\text { All traffic police motor cyclists } \\
\text { in one city (Japan) }\end{array}$ & $119(\mathrm{R}=100 \%)$ & $\begin{array}{l}\text { Prevalence of symptoms: } \\
\text { high } v \text { low vibration dose, pain, } 20.6 \% v 2.0 \% \\
(\mathrm{p}<0.05) \text {; stiffness, } 55.9 \% v 20.4 \%(\mathrm{p}<0.05)\end{array}$ \\
\hline 40 & 47 & $\begin{array}{l}\text { Shoulder symptoms in the } \\
\text { past } 7 \text { days (NQ) }\end{array}$ & $\begin{array}{l}\text { Assembly workers in factory } \\
\text { (Sweden). }\end{array}$ & $\begin{array}{l}148 / \text { ? Assembly } \\
\text { workers } \\
\text { ( } \mathrm{R}=\text { not reported) }\end{array}$ & $\begin{array}{l}\mathrm{LR}(\mathrm{OR} \text { adjusted for age and duration of employment, } \\
\text { graphical display) work pace, medium, } 7(\mathrm{p}<0.001) \\
\text { fast, } 10(\mathrm{p}<0.001) \text {; very fast, } 1.5\end{array}$ \\
\hline 41 & 47 & $\begin{array}{l}\text { Shoulder symptoms in the } \\
\text { past } 12 \text { months }(\mathrm{Q})\end{array}$ & $\begin{array}{l}\text { Members of the dentists' } \\
\text { association, Malmö (Sweden) }\end{array}$ & $359 / 395(\mathrm{R}=91 \%)$ & $\begin{array}{l}\text { Univariate correlations (stratified by sex) } \\
\text { years in practice, } p<0.05 ; \text { position relative to patient, } \\
\mathrm{p}<0.05 \text {; use of mirror, } \mathrm{p}<0.05\end{array}$ \\
\hline 42 & 47 & $\begin{array}{l}\text { Shoulder pain (case } \\
\text { definition unclear) }\end{array}$ & $\begin{array}{l}\text { Lorry truck drivers, partly } \\
\text { random selection (The } \\
\text { Netherlands) }\end{array}$ & $534 / 975(\mathrm{R}=55 \%)$ & $\begin{array}{l}\mathrm{LR}(\mathrm{OR}, 90 \% \mathrm{CI} \text {, adjusted for age) } \\
\text { pallet loading, } 2.1(1.3 \text { to } 3.6) \text {; wheeled cages, } 2.0 \text { (1.1 } \\
\text { to } 3.7) \text {; packed goods, } 2.3(1.3 \text { to } 3.9)\end{array}$ \\
\hline 43 & 43 & $\begin{array}{l}\text { Shoulder pain during the } \\
\text { past year (NQ) }\end{array}$ & $\begin{array}{l}\text { All medical secretaries and } \\
\text { office personnel in hospital } \\
\text { (Sweden) }\end{array}$ & $420 / 438(\mathrm{R}=96 \%)$ & $\begin{array}{l}\text { Univariate } \chi^{2} \text { analysis, OR } \\
\text { poor work content, } 2.5(1.3 \text { to } 4.9) \\
\text { poor social support, } 1.6 \text { (1.0 to } 2.8)\end{array}$ \\
\hline \multicolumn{6}{|c|}{ Design and results of case-control studies on occupational risk factors for shoulder pain } \\
\hline 44 & 67 & $\begin{array}{l}\text { Specific shoulder disorders } \\
(\text { Ex) }\end{array}$ & $\begin{array}{l}\text { Attenders orthopaedic clinics } \\
\text { (UK) } \\
\text { Controls, attenders without } \\
\text { disease upper limb }\end{array}$ & $\begin{array}{l}1564 / 1677(\mathrm{R}=93 \%) \\
580 \text { cases }\end{array}$ & $\begin{array}{l}\text { LR (OR adjusted for age) } \\
\text { repeated elbow flexion, } 0.4(0.2 \text { to } 0.8) \\
\text { repeated shoulder rotation with elevated arm, } 2.3 \\
(\mathrm{p}<0.05)\end{array}$ \\
\hline 45 & 43 & $\begin{array}{l}\text { Shoulder pain and disability } \\
\geqslant 24 \mathrm{~h} \text { in past month }(\mathrm{Q})\end{array}$ & $\begin{array}{l}\text { Random selection of } 500 \\
\text { patients from a general practice } \\
\text { (UK) }\end{array}$ & $\begin{array}{l}217 / 500(\mathrm{R}=66 \%) \\
39 \text { Cases }\end{array}$ & $\begin{array}{l}\text { Univariate LR (RR stratified by sex), monotonous } \\
\text { work, } 2.7 \text { ( } 1.3 \text { to } 5.4 \text { ) for men, } \\
\text { weights on one shoulder, } 5.5 \text { ( } 1.8 \text { to } 17.4) \text {; always } \\
\text { damp, } 5.4(1.6 \text { to } 19) \text {; arms above shoulder level, } 2.1 \\
\text { (0.8 to } 5.8) \text {; always cold, } 6.4 \text { ( } 1.5 \text { to } 27) \text {; always hot, } \\
2.4(0.7 \text { to } 7.9) \text {; always noisy, } 2.2(0.7 \text { to } 6.5) \text {; } \\
\text { for women, always damp, } 3.3 \text { (0.4 to } 27)\end{array}$ \\
\hline 46 & 37 & $\begin{array}{l}\text { Shoulder pain }>3 \text { months } \\
\text { (Ex) }\end{array}$ & $\begin{array}{l}\text { Manual workers attending } \\
\text { healthcare centre (Sweden) } \\
\text { Controls, manual workers }(2,1)\end{array}$ & $\begin{array}{l}17 / 20 \text { cases }(R=85 \%) \\
34 \text { controls }\end{array}$ & $\begin{array}{l}\text { Univariate (OR based on } 2 \times 2 \text {-table), } \\
\text { arms at or above shoulder, } 10.6(2.8 \text { to } 40.9)\end{array}$ \\
\hline
\end{tabular}

$\star$ Positive findings, the association between the risk factor at issue and the occurrence of shoulder pain is strong $(\mathrm{OR}$ or $\mathrm{RR}>2.0$ or $<0.5)$ or significant $(\mathrm{p}<0.05)$. Risk estimates (OR/RR) are presented with corresponding $95 \%$ confidence interval (if sufficient data were available from the original publications). tOnset of complaints on the current job or symptoms are assumed to be related to the current job.

Additional details on the methods and results of the studies included in this review can be obtained from the corresponding author.

$\mathrm{Ex}=$ physical examination; $\mathrm{Q}=$ questionnaire; $\mathrm{NQ}=$ Nordic questionnaire; ${ }^{47} \mathrm{R}=$ response rate; $\mathrm{Obs}=\mathrm{observation} ; \mathrm{LR}=$ logistic regression; $\mathrm{OR}=\mathrm{odds}$ ratio; $\mathrm{RR}=$ relative risk.

of the four good quality studies that reported positive associations for job control had defined shoulder pain as symptoms with an onset during the current job, ${ }^{1722} 24$ whereas only one of the studies with negative findings had made that distinction. ${ }^{26}$ This finding may increase the strength of evidence for job control as a risk factor for shoulder pain.

\section{Discussion}

This systematic review evaluated the results of 29 studies on occupational risk factors for shoulder pain. Variables related to both physical load and the psychosocial work environment were associated with the occurrence of shoulder pain. The review found substantial heterogeneity across studies for study setting, exposures measured, methods of exposure assessment, statistical analysis, and data presentation. This heterogeneity impeded sensible statistical pooling of results, and hence, a qualitative summary was undertaken. The available evidence was not consistent for most risk factors, not of generally high methodological quality, and the strength of the associations was modest.

The strengths of associations were difficult to interpret due to the heterogeneity across studies, but also due to the use of the OR in most cross sectional studies. The prevalence of shoulder pain was often high, which reduces the reliability of the OR as an estimate of the relative risk, and results in an overestimation of the magnitude of the association. ${ }^{2145}$ Only a few studies have considered these difficulties and have presented relative risks or prevalence rate ratios instead of, or as well as ORs. ${ }^{2127} 29$

\section{QUALITY APPRAISAL}

All items of our methodological checklist received equal weight. This has the disadvantage that studies with only few, but very important flaws, may still be ranked among the best 
Table 4 Summary of the strength of evidence of risk factors for shoulder pain

\begin{tabular}{|c|c|c|c|c|}
\hline & Study references & Consistency of findings & Strength of association: $(O R / R R)^{\star}$ & $\begin{array}{l}\text { Median method score: } \\
\%\end{array}$ \\
\hline Heavy physical load & $\begin{array}{l}M S \geqslant 60 \%: \\
17,20,23,26,27,28,29 \\
M S<60 \%: \\
30,34,35,36,37,42,45,46\end{array}$ & $\begin{array}{l}\text { MS } \geqslant 60 \%: 3 / 7=43 \% \text { positive } \\
\text { MS }<60 \%: 4 / 7=57 \% \text { positive }\end{array}$ & $\begin{array}{l}M S \geqslant 60 \%: 1.7,3.6,5.4 \\
M S<60 \%: 2.0 \text { to } 2.3,5.5, ?\end{array}$ & No association: 60 \\
\hline Awkward postures & $\begin{array}{l}\text { MS } \geqslant 60 \%: 17,19,20,26,29,44 \\
M S<60 \%: \\
30,31,33,37,41,45,46\end{array}$ & $\begin{array}{l}\text { MS } \geqslant 60 \%: 3 / 6=50 \% \text { positive } \\
\text { MS }<60 \%: 7 / 7=100 \% \text { positive }\end{array}$ & $\begin{array}{l}M S \geqslant 60 \%: 1.4,1.6,2.8 \rightarrow 3.1 \\
M S<60 \%: 2.1,5.1,10.6, ?\end{array}$ & $\begin{array}{l}\text { Positive findings: } 56 \\
\text { No association: } 71\end{array}$ \\
\hline Repetitive movements & $\begin{array}{l}M S \geqslant 60 \%: 17,26,44 \\
M S<60 \%: 31,33,37,40,45\end{array}$ & $\begin{array}{l}\text { MS } \geqslant 60 \%: 3 / 3=100 \% \text { positive } \\
\text { MS }<60 \%: 3 / 5=60 \% \text { positive }\end{array}$ & $\begin{array}{l}M S \geqslant 60 \%: 1.6,2.3,46 \\
M S<60 \%: 7 \rightarrow 10 \rightarrow 1.5, ?\end{array}$ & $\begin{array}{l}\text { Positive findings: } 59 \\
\text { No association: } 48\end{array}$ \\
\hline $\begin{array}{l}\text { Same activity for a prolonged period } \\
\text { of time }\end{array}$ & $\begin{array}{l}M S \geqslant 60 \%: 24,25,27 \\
M S<60 \%: 32,33\end{array}$ & $\begin{array}{l}\text { MS } \geqslant 60 \%: 1 / 3=33 \% \text { positive } \\
\text { MS }<60 \%: 2 / 2=100 \% \text { positive }\end{array}$ & $\begin{array}{l}\text { MS } \geqslant 60 \%: 1.6 \\
M S<60 \%: 1.9,18.8\end{array}$ & $\begin{array}{l}\text { Positive findings: } 53 \\
\text { No association: } 65\end{array}$ \\
\hline Vibration & $\begin{array}{l}\text { MS } \geqslant 60 \%: 18,23 \\
M S<60 \%: 36,37,39,45\end{array}$ & $\begin{array}{l}\text { MS } \geqslant 60 \%: 2 / 2=100 \% \text { positive } \\
\text { MS <60\%: } 2 / 4=50 \% \text { positive }\end{array}$ & $\begin{array}{l}\text { MS } \geqslant 60 \%: 1.04 / y, 2.6 \\
M S<60 \%: ?\end{array}$ & $\begin{array}{l}\text { Positive findings: } 57 \\
\text { No association: } 45\end{array}$ \\
\hline Duration of employment & $\begin{array}{l}M S \geqslant 60 \%: 19,22,23,24 \\
M S<60 \%: 30,32,36,40,41,43\end{array}$ & $\begin{array}{l}\text { MS } \geqslant 60 \%: 3 / 4=75 \% \text { positive } \\
\text { MS }<60 \%: 3 / 6=50 \% \text { positive }\end{array}$ & $\begin{array}{l}M S \geqslant 60 \%: 1.4,3.9 \rightarrow 2.1,2.3 \rightarrow 3.2 \\
M S<60 \%: 1.9, ?\end{array}$ & $\begin{array}{l}\text { Positive findings: } 62 \\
\text { No association: } 47\end{array}$ \\
\hline Psychological work demands & $\begin{array}{l}M S \geqslant 60 \%: \\
17,20,21,22,24,25,26,27 \\
M S<60 \%: 30,31,32,36,37,45\end{array}$ & $\begin{array}{l}\text { MS } \geqslant 60 \%: 4 / 8=50 \% \text { positive } \\
\text { MS }<60 \%: 4 / 6=67 \% \text { positive }\end{array}$ & $\begin{array}{l}M S \geqslant 60 \%: 1.5,1.5,1.5,1.7 \\
M S<60 \%: ?\end{array}$ & $\begin{array}{l}\text { Positive findings: } 59 \\
\text { No association: } 68\end{array}$ \\
\hline Job control & $\begin{array}{l}M S \geqslant 60 \%: \\
17,21,22,24,25,26,27 \\
M S<60 \%: 31,32,37,38\end{array}$ & $\begin{array}{l}\text { MS } \geqslant 60 \%: 4 / 7=57 \% \text { positive } \\
\text { MS }<60 \%: 2 / 4=50 \% \text { positive }\end{array}$ & $M S \geqslant 60 \%: 1.6,1.7,1.9,4.0$ & $\begin{array}{l}\text { Positive findings: } 68 \\
\text { No association: } 65\end{array}$ \\
\hline Social support & $\begin{array}{l}\text { MS } \geqslant 60 \%: \\
17,20,21,24,25,26,27 \\
\text { MS <60\%: } 31,32,37,38,43\end{array}$ & $\begin{array}{l}M S \geqslant 60 \%: 0 / 7=0 \% \text { positive } \\
M S<60 \%: 3 / 5=60 \% \text { positive }\end{array}$ & $\begin{array}{l}\mathrm{MS} \geqslant 60 \%:- \\
\mathrm{MS}<60 \%: 1.6, ?\end{array}$ & No association: 65 \\
\hline Job satisfaction / stimulation at work & $\begin{array}{l}M S \geqslant 60 \%: 17,21,25,26,27 \\
M S<60 \%: \\
30,31,35,36,37,38,43,45\end{array}$ & $\begin{array}{l}\text { MS } \geqslant 60 \%: 3 / 5=60 \% \text { positive } \\
\text { MS <60\%: } 3 / 7=43 \% \text { positive }\end{array}$ & $\begin{array}{l}\text { MS } \geqslant 60 \%: 1.3,1.5,2.7 \\
M S<60 \%: 2.5, ?\end{array}$ & $\begin{array}{l}\text { Positive findings: } 59 \\
\text { No association: } 53\end{array}$ \\
\hline
\end{tabular}

*Some studies, particularly those with relatively poor method scores, did not present ORs or RRs. Other indicators of the strength of the association between exposures and shoulder pain (correlation coefficients, $\mathrm{p}$ values) are presented in table 3.

$\mathrm{MS}=$ method score (median method score was $60 \%$ ).

studies. The three highest ranked studies, for example, did not receive positive scores for response rate (item 4), ${ }^{17-19}$ which may be considered to be an important aspect of methodological quality. Readers who consider certain items to be particularly important may use the information from tables 2 and 3 to conduct their own sensitivity analyses. The same holds for the cut off point we used to identify studies of relatively good quality (the median score of $60 \%$ ), and our definition of consistency of findings (75\%).

A few items did not discriminate well among studies, and could be omitted from the checklist. For example, item 1 (description of research objective) scored positive in almost all studies. A few other items were also not very useful in identifying high quality studies, as they were rated negative for most studies. These items $(11,12,13$, and 15), however, may represent important potential flaws. Future studies should aim to prevent these shortcomings, although that may be difficult to achievefor example, blinding of assessment of exposure to disease status.

VALIDITY OF THE STUDIES IN THE REVIEW Exposure during leisure time or occupational exposure in the past were often not evaluated. These variables are important potential confounders of the association between current occupational exposures and shoulder pain. The most important limitation of research to date, however, is the lack of longitudinal research, which makes it difficult to establish whether the risk factors appraised actually preceded the occurrence of shoulder pain. Temporality may be considered to be the only valid criterion for causality. ${ }^{48}$ Cross sectional studies with a case definition that includes only symptoms with an onset during the current job (table 3) may, therefore, be preferred to cross sectional studies that do not seem to check whether the exposure actually preceded the onset of shoulder problems.

Information bias can result from differential or non-differential misclassification and can accordingly influence the estimate of the strength of the association. Information bias can only be prevented by attempting to blind assessment of exposure to disease status or vice versa. These measures were rarely taken by the studies included in the review. Finally, cross sectional studies have a potential risk for survivor bias (healthy worker effect). Workers who develop shoulder pain may have left the workplace or selected different jobs, which may not be accounted for in cross sectional designs. ${ }^{7}$ This phenomenon will tend to underestimate the magnitude of an association. Ohlsson et $a l^{40}$ for example, showed that for younger subjects the odds of having shoulder pain increased considerably with the duration of employment, whereas for older workers there was no significant change with duration of employment. Among the reasons that may explain this discrepency is survivor bias - that is, the selective leaving of workers with shoulder pain, and healthier subjects remaining in the job.

Longitudinal research is costly and may be a challenge to the investigator. Monotonous jobs or jobs with high work loads may have a high turnover of personnel, with difficulties tracing workers who have left the job. Work conditions 
and exposures may alter during the study, complicating the interpretation of results. Nevertheless, the development of improved methods of exposure assessment and the availability of user friendly statistical software for the analysis of longitudinal data, will facilitate the design and conduction of high quality prospective cohort studies on occupational risk factors for shoulder pain.

CAUSES OF SHOULDER PAIN

It seems likely that shoulder pain is the result of a concerted action of many factors, including individual factors, physical work load factors, and the psychosocial work environment. Several authors have proposed multifactorial models to explain the aetiology of musculoskeletal problems, and more specifically shoulder pain. ${ }^{114950}$ Increased levels of muscle activity with few periods of low activity (micropauses) during awkward and static postures, and during repetitive movements, may result in shoulder pain. ${ }^{51-53}$ Psychosocial factors seem to be important in both the development and maintenance of subacute and chronic problems. Pain behaviour may be learned over time and may eventually cause the pain problem to persist even after physical healing has occurred. In this model pain is considered to be more than a neurophysiological entity, having both cognitive and behavioural dimensions. ${ }^{49} \mathrm{~A}$ poor social work environment, together with an inadequate personal capacity to cope with these factors, may increase work related stress. The increase in stress may increase muscle tone directly, or strengthen the relation between physical work load and musculoskeletal symptoms. This may result in an enhancement of the perception or reporting of symptoms, or a reduction of the capacity to cope..$^{911}$

CONCLUSIONS AND RECOMMENDATIONS

In summary, both physical load and the psychosocial work environment seem to be associated with shoulder pain. However, the available evidence was not consistent for most risk factors, not of generally high quality (method score $\geqslant 60 \%$ in 14 out of 29 studies), and the associations were generally not strong. In studies of relatively good methodological quality, however, consistent positive associations were found for repetitive movements, vibration, duration of employment, and to a lesser extent, job dissatisfaction.

Study of the aetiology of shoulder pain still faces many challenges for the assessment of exposure, development of adequate case definitions, and in particular, the design of longitudinal research. Prospective cohort studies that evaluate new and current employees for musculoskeletal symptoms and provide periodical follow up assessments, will provide valuable information on temporal and doseresponse relations. To establish the relative contribution of each risk factor and the role of potential confounding variables, studies should evaluate not only physical work load factors and the psychosocial work environment, but also exposures in the past and during leisure time. Such studies will provide the information needed to set priorities for the prevention of work related shoulder pain.

This study was financially supported by the Netherlands Organisation for Scientific Research (NWO), grant no. R96-173.

1 Badley EM, Tennant A. Changing profile of joint disorders with age: findings from a postal survey of the population of Calderdale, West Yorkshire, United Kingdom. Ann Rheum Dis 1992;51:366-71.

2 Bjelle A. Epidemiology of shoulder problems. Baillières Clin Rheumatol 1989;3:437-51.

3 Nygren A, Berglund A, Von Koch M. Neck and shoulder pain, an increasing problem. Strategies for using insurance material to follow trends. Scand $\mathcal{F}$ Rehabil Med Suppl 1995; 32:107-12.

4 Gerr F, Letz R, Landrigan PJ. Upper-extremity musculoskeletal disorders of occupational origin. Anпи Rev Public Health 1991;12:543-66.

5 Wallace M, Buckle P. Ergonomic aspects of neck and upper limb pain. International Reviews of Ergonomics 1987;1:173200.

6 Hagberg M, Wegman DH. Prevalence rates and odds ratios of shoulder-neck diseases in different occupational groups. Br f Ind Med 1987;44:602-10.

7 Stock SR. Workplace ergonomic factors and the development of musculoskeletal disorders of the neck and upper limbs: a meta-analysis. Am f Ind Med 1991;19:87-107.

8 Winkel J, Westgaard R. Occupational and individual risk factors for shoulder-neck complaints: part II The scientific basis (literature review) for the guide. Int f Ind Ergon 1992; 10:85-104.

9 Hales TR, Bernard BP. Epidemiology of work-related musculoskeletal disorders. Orthop Clin North Am 1996;27: 679-709.

10 Sommerich CM, McGlothlin JD, Marras WS. Occupational risk factors associated with soft tissue disorders of the shoulder: a review of recent investigations in the literature. Ergonomics 1993;36:697-717.

11 Bongers PM, De Winter CR, Kompier MAJ, et al. Psychosocial factors at work and musculoskeletal disease. Scand 7 Work Environ Health 1993;19:297-312.

12 Ariëns GAM, Van Mechelen W, Bongers PM, et al. Physical risk factors for neck pain: a systematic review. Scand $\mathcal{F}$ Work risk factors for neck pain: a syst
Environ Health 2000;26:7-19.

13 Hoogendoorn WE, Van Poppel MNM, Bongers PM, et al. Systematic review of physical load at work and in leisure time as risk factors for low back pain. Scand $\mathcal{F}$ Work Environ Health 1999;25:387-403.

14 DerSimonian R, Laird N. Meta-analysis in clinical trials. Controlled Clin Trials 1986;7:177-88.

15 Greenland S. A critical look at some popular meta-analytic methods. Am $\mathcal{F}$ Epidemiol 1994;140:290-6.

16 Hill AB. The environment and disease: association or causation? Proc R Soc Med 1965;58:295-300.

17 Hughes RE, Silverstein BA, Evanoff BA. Risk factors for work-related musculoskeletal disorders in an aluminum smelter. Am f Ind Med 1997;32:66-75.

18 Burdorf A, Monster A. Exposure to vibration and self-reported health complaints of riveters in the aircraft industry. Ann Occup Hyg 1991;35:287-9.

19 Liss GM, Jesin E, Kusiak RA, et al. Musculoskeletal problems among Ontario dental hygienists. Am f Ind Med 1995;28:521-40.

20 Burdorf A, Van Riel M, Brand T. Physical load as risk factor for musculoskeletal complaints among tank terminal workers. Am Ind Hyg Assoc F 1997;58:489-97.

21 Lagerström M, Wenemark M, Hagberg $M$, et al. Occupational and individual factors related to musculoskeletal symptoms in five body regions among Swedish nursing personnel. Int Arch Occup Environ Health 1995;68:27-35.

22 Lemasters GK, Atterbury MR, Booth-Jones AD, et al. Prevalence of work related musculoskeletal disorders in active union carpenters. Occup Environ Med 1998;55:4217 .

23 Stenlund B, Goldie I, Hagberg M, et al. Shoulder tendinitis and its relation to heavy manual work and exposure to vibration. Scand f Work Environ Health 1993;19:43-9.

24 Bernard B, Sauter S, Fine L, et al. Job task and psychosocial risk factors for work-related musculoskeletal disorders risk factors for work-related musculoskeletal disorders 1994; 20:417-26.

25 Hales TR, Sauter SL, Peterson MR, et al. Musculoskeletal disorders among visual display terminal users in a telecommunications company. Ergonomics 1994;37:1603-21.

26 Johansson JA. Psychosocial work factors, physical work load and associated musculoskeletal symptoms among home care workers. Scand $\mathcal{F}$ Psychol 1995;36:113-29.

27 Skov T, Borg V, Ørhede E. Psychosocial and physical risk factors for musculoskeletal disorders of the neck, shoulders, and lower back in salespeople. Occup Environ Med 1996;53:351-6.

28 Jacobsson L, Lindgärde F, Manthorpe R, et al. Effect of education, occupation, and some lifestyle factors on common rheumatic complaints in a Swedish group aged $50-70$ years. Ann Rheum Dis 1992;51:835-43.

29 Sobti A, Cooper C, Inskip H, et al. Occupational physical activity and long-term risk of musculoskeletal symptoms: a national survey 
30 Kilbom A, Persson J, Jonsson BG. Disorders of the cervicobrachial region among female workers in the electronic
industry. International fournal of Industrial Ergonomics industry. Inter

31 Johansson JA, Rubenowitz S. Risk indicators in the psychosocial and physical work environment for work-related neck, shoulder and low back symptoms: a study among
blue and white collar workers in eight companies. Scand $\mathscr{f}$ blue and white collar workers
Rehabil Med 1994;26:131-42.

32 Kamwendo K, Linton SJ, Moritz U. Neck and shoulder disorders in medical secretaries. Part I. Pain prevalence and risk factors. Scand F Rehabil Med 1991;23:127-33.

33 Yu ITS, Wong TW. Musculoskeletal problems among VDU workers in a Hong Kong bank. Occup Med 1996;46:27580.

34 Bergenudd H, Lindgärde F, Nilsson B, et al. Shoulder pain in middle age. A study of prevalence and relation to occupational, work load and psychosocial factors. Clin Orthop 1988;231:234-8.

35 Bergenudd $\mathrm{H}$, Nilsson B. The prevalence of locomotor complaints in middle age and their relationship to health and socioeconomic factors. Clin Orthop 1994;308:264-70.

36 Dimberg L, Olafsson A, Stefansson E, et al. The correlation Dimberg L, Olafsson A, Stefansson E, et al. The correlation between work environment and the occurrence of
brachial symptoms. $\mathcal{F}$ Occup Med 1989;31:447-53.

37 Johansson JA, Kadefors R, Rubinowitz S, et al. Musculoskeletal symptoms, ergonomic aspects, and psychosocia factors in two different truck assembly concepts. Int f Ind Ergon 1993;12:35-48

38 Silverstein BA, Hughes RE. Upper extremity musculoskeletal disorders at a pulp and paper mill. Appl Ergon 1996;27:189-94.

39 Mirbod SM, Yoshida H, Jamali M, et al. Assessment of hand-arm vibration exposure among traffic police motorcyclists. Int Arch Occup Environ Health 1997;70:22-8.

40 Ohlsson K, Attewell R, Skerfving S. Self-reported symptoms in the neck and upper limbs of female assembly workers. Scand $\mathcal{F}$ Work Environ Health 1989;15:75-80.

41 Rundcrantz B-L, Johnsson B, Moritz U. Cervical pain and discomfort among dentists. Epidemiological, clinical and therapeutic aspects. Swed Dent F 1990;14:71-80
42 Van der Beek AJ, Frings-Dresen MHW, Van Dijk FJH, et al. Loading and unloading by lorry drivers and musculoskeletal complaints. International fournal of Industrial Ergonomics 1993;12:13-23.

43 Linton SJ, Kamwendo K. Risk factors in the psychosocial work environment for neck and shoulder pain in secretaries. F Occup Med 1989;31:609-13.

44 English CJ, Maclaren WM, Court-Brown C, et al. Relations between upper limb soft tissue disorders and repetitive movements at work. Am F Ind Med 1995;27:75-90.

45 Pope DP, Croft PR, Pritchard CM, et al. Occupational factors related to shoulder pain and disability. Occup Environ Med 1997;54:316-21.

46 Bjelle A, Hagberg M, Michaelsson G. Clinical and ergonomic factors in prolonged shoulder pain among industrial workers. Scand 7 Work Environ Health 1979;5: 205-10.

47 Kuorinka I, Jonsson B, Kilbom A, et al. Standardised Nordic questionnaires for the analysis of musculoskeletal symptoms. Appl Ergon 1987;18:233-7.

48 Rothman KJ, Greenland S. Causation and causal inference. In: Rothman KJ, Greenland S, eds. Modern epidemiology, 2nd ed. Philadelphia: Lippincott Raven, 1998:7-28.

49 Linton SJ. An overview of psychosocial and behavioral factors in neck-and-shoulder pain. Scand $\mathcal{f}$ Rehabil Med Suppl 1992;32:67-77

50 Kilbom A. Intervention programmes for work-related neck and upper limb disorders: strategies and evaluation. Ergonomics 1988;31:735-47.

51 Erdelyi A, Sihvonen T, Helin P, et al. Shoulder strain in keyboard workers and its alleviation by arm supports. Int Arch Occup Environ Health 1988;60:119-24.

52 Hägg GM, Åström A. Load pattern and pressure pain threshold in the upper trapezius muscle and psychosocial factors in medical secretaries with and without shoulder/ neck disorders. Int Arch Occup Environ Health 1997;69: 423-32.

53 Veiersted KB, Westgaard RH, Andersen P. Electromyographic evaluation of muscular work pattern as a predictor graphic evaluation of muscular work pattern as a predictor
of trapezius myalgia. Scand $\mathcal{f}$ Work Environ Health 1993;19: $284-90$. 